\title{
SERVICE QUALITY, CUSTOMER SATISFACTION AND LOYALTY IN BANKING SECTOR OF PAKISTAN
}

Babar Nawaz Abbasi ${ }^{1}$ Muhammad Umer ${ }^{2}$ Ali Sohail ${ }^{3}$ Jingjing Tang $^{4}$ Ihsan Ullah $^{5}$ Hifza Abbasi $^{6}$

1, ${ }^{3,4}$ Center for Experimental Economics in Education, Shaanxi Normal University, Xi'an

Shaanxi, China

${ }^{2}$ Institute of Management Sciences KPk Peshawar-Pakistan

${ }^{5}$ University of Peshawar Statistics Department

${ }^{6}$ Federal College of Education Islamabad-Pakistan

*Corresponding Author: Babar Nawaz Abbasi

Corresponding Author Email: babarnawaz205@yahoo.com

Article Received: 21-03-19 Accepted: 31-03-19

Published: 05-04-19

Licensing Details: Author retains the copyright of this article. The article is distributed under the terms of the Creative Commons Attribution-NonCommercial $4.0 \quad$ Licence (http://www.creativecommons.org/licences/by-nc/4.0/) which permits non-commercial use, reproduction and distribution of the work without further permission provided the original work is attributed as specified on the Journal open access page.

\begin{abstract}
The major purpose of the research paper is to measure the quality of service offered by private banks operating in Pakistan. Moreover, it tries to investigate the relationship between service quality, customer satisfaction and loyalty. In order for a bank offer to reach the customers, there is a need for services. These services depend on the type of product and it differs in the various organizations. Service can be defined as an intangible offer by one party to another in exchange of money for Service quality in the management and marketing literature is the extent to which customers' perceptions of service meet and/or exceed their expectations. Thus service quality can intend to be the way in which customers are served in an organization which could be good or poor. A loyalty program may give a customer advanced access to new products, special sales coupons or free merchandise. Our study shows the three basic aspects of a customer in the banking sector which are service quality, customer satisfaction and banking loyalty in the banking sector. The findings of our study show that most of our respondents are well satisfied with banking services to provide by different commercial and Islamic banks such as HBL, UBL, NBP, MCB etc. in Peshawar sadder. The services provided by the banks particularly ATM
\end{abstract}


machines are very praised by the customers. The loyalty provided to customers by the banks was also very good and most of the respondents were satisfy from that but there were also some major problems in these banking sectors for customers which should be handled as soon as possible for their good services we also find out that the banking policies for customer services and to maintain loyalty with customer should be enhanced more precisely.

Key Words: Service Quality, Customer Satisfaction, Customer's Loyalty.

\section{INTRODUCTION}

Customer are highly important for businesses especially after the marketing era launched during 1950s. During this era, companies started to focus on customer needs and produced more customized products. Now customer satisfaction is becoming a great topic of interest for researchers and organizations around the world. Every organization tries to achieve customer satisfaction in order to make profit and grow. In this study, the focus is on customer satisfaction.

\section{Customer Satisfaction}

Customer are those individuals who buy our products and services. Thus, customer is an important stakeholder of organization who provide income to the organization. Marketing literature differentiate between customer and consumer as customer is someone who purchase your product; while, consumer is someone who consume the product.

\section{Statement of the Problems}

1: Offensive and poor attitude and behavior on the bank's staff in their dealings with actual and potential customers.

2: Inadequate facilities and equipment required to provide modern banking services.

3: Absence of frequent training programs for the staff to shape up their attitude towards customers.

4: Unduly long processes in responding to customer's needs.

5: Excessive competition from banks which perform commercial banking services.

\section{Service Quality}

Services plays important role in any country's economy. There are various services offered by service oriented firms. Generally, service refers to any intangible act or performance which is offered by one party to another. Generally, services are offered for exchange of money or similar. The concept of service quality has gained a lot of interest in marketing literature and work of Zeithaml is one of the classic one in this domain. Service quality is about the quality of services offered by an organization to its customer.

\section{Customer Loyalty}

Customer loyalty program is about rewarding customer for their repeated purchase. It can be in the form of free merchandize, points system, or special sales coupons which can be redeemed by the customer. Mostly, customer loyalty program are based on customer registration with the firm and recording sales made by that customer over period of time. Organizations such as airline, or restaurants offers customer reward for their repeated purchase.

\section{Objectives Of The Study}

1: To evaluate the level of service quality at the Banking sector. 
2: To examine the customer satisfaction at the Banking sector.

3: To examine the banking loyalty with the customer at banking sector.

4: To find out the problems faced by customers at the banking sector.

\section{RESEARCH METHODOLOGY}

This section provide details about research methodology.

\section{Study Area}

The role of commercial banks in the Economic Development of a country cannot be defined. Banks have always been playing role in bringing out a country from depression with its monetary and fiscal tools for example taxation, interest rate etc. Therefore the banks of Pakistan as a whole have been taken as a study area.

\section{Target Population}

In our survey, our target population is different Banks of Peshawar KPK Peshawar.

\section{Sampled Population}

For meeting the need of my survey, I collected information from the people of Peshawar Saddar. The respondents were belonging to different areas of Peshawar Saddar.

\section{Method Of Inquiry}

The questionnaire method is used through simple random sampling to meet the need of my survey the questionnaire has been given to each person and they filled it in a proper manner.

\section{Sample Size}

For my survey, I take the size of 30 from different individuals of Peshawar Saddar.

\section{Duration Of The Study}

The study continued for approximately six months where a planning for review, data collection and report had been framed.

\section{Limitations Of The Study}

There were many limitations of the study such as time was short. Due to the shortage of time researcher had to shorten the sample size and research area. It was hard to collect data from the Islamic banking customers as it was only possible in the Islamic banks and customers were not much willing to give information because of time shortage or because of the bank where it does not look good to be interviewed.

\section{DATA ANALYSIS}

Data collected through the above material instrument were tabulated; analyzed and interrupted. The analysis was done through SPSS by using.

\section{Descriptive Analysis}

\begin{tabular}{|l|c|c|}
\hline & Frequency & Percent \\
\hline Male & 21 & 70.0 \\
\hline Female & 9 & 30.0 \\
\hline Total & 30 & 100.0 \\
\hline
\end{tabular}




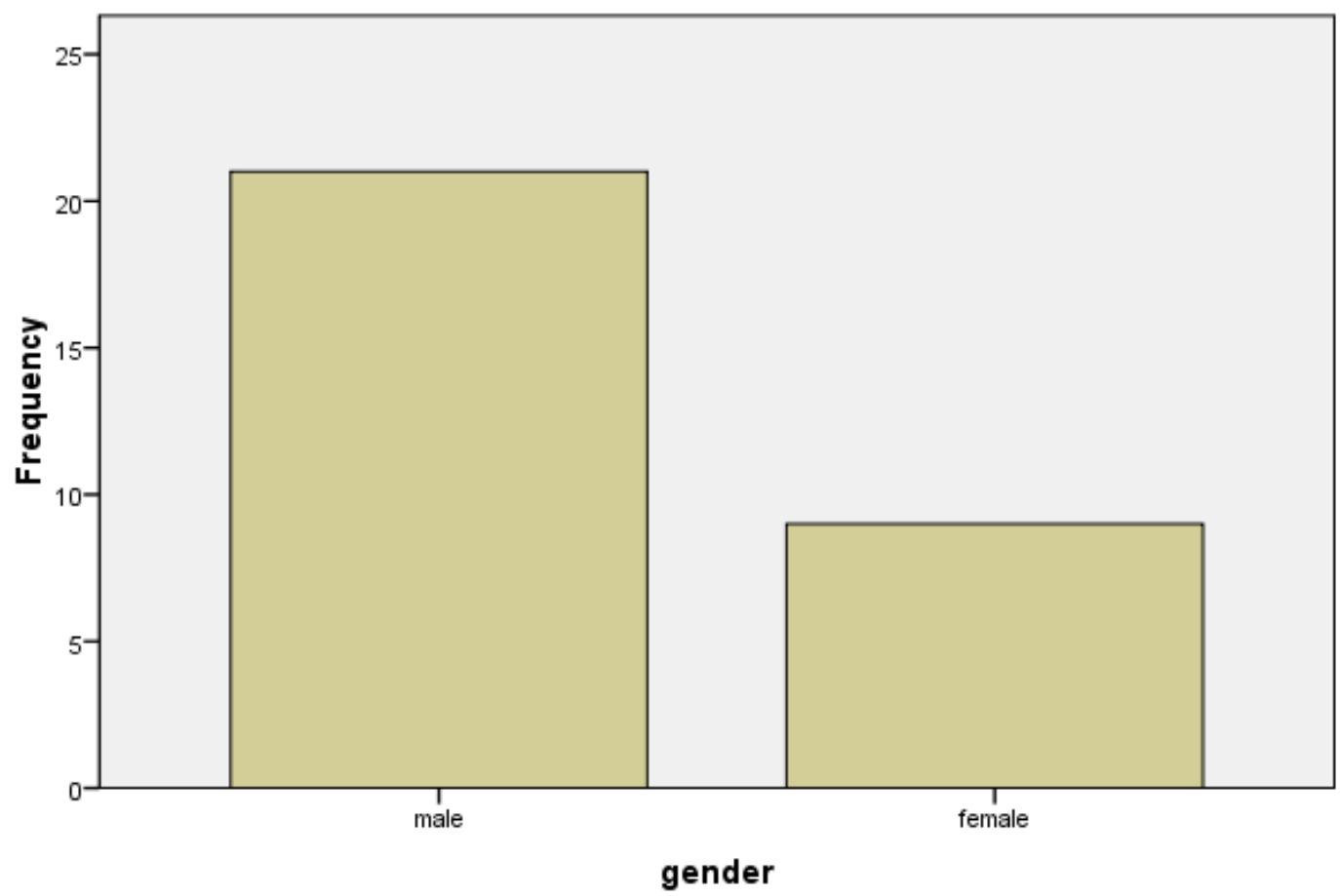

Figure 1: Gender

The above table and figure shows the gender distribution of the respondents. According to the results, $21(70 \%)$ out of 30 are male and $9(30 \%)$ out of 30 respondents are female.

Table 2: Age of respondent

\begin{tabular}{|l|c|c|}
\hline & Frequency & Percent \\
\hline up to 20 years & 1 & 3.3 \\
\hline between 20 to 30 years & 20 & 66.7 \\
\hline above 30 years & 9 & 30.0 \\
\hline Total & 30 & 100.0 \\
\hline
\end{tabular}

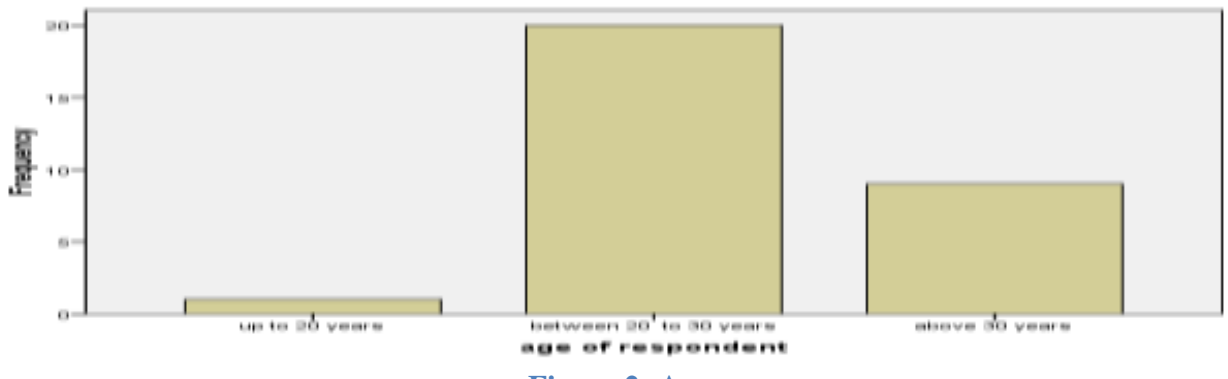

Figure 2: Age 
The above table and figure show the distribution of the age of respondents the results show that the age of respondents up to 20 years is $1(3.3 \%)$, the age of respondents between 20 years and 30 years are $20(66.7 \%)$ and age above 30 years is $7(30 \%)$.

Table 3: Occupation of respondent

\begin{tabular}{|l|c|c|}
\hline & Frequency & Percent \\
\hline government job & 8 & 26.7 \\
\hline private job & 12 & 40.0 \\
\hline Student & 9 & 30.0 \\
\hline housewife & 1 & 3.3 \\
\hline Total & 30 & 100.0 \\
\hline
\end{tabular}

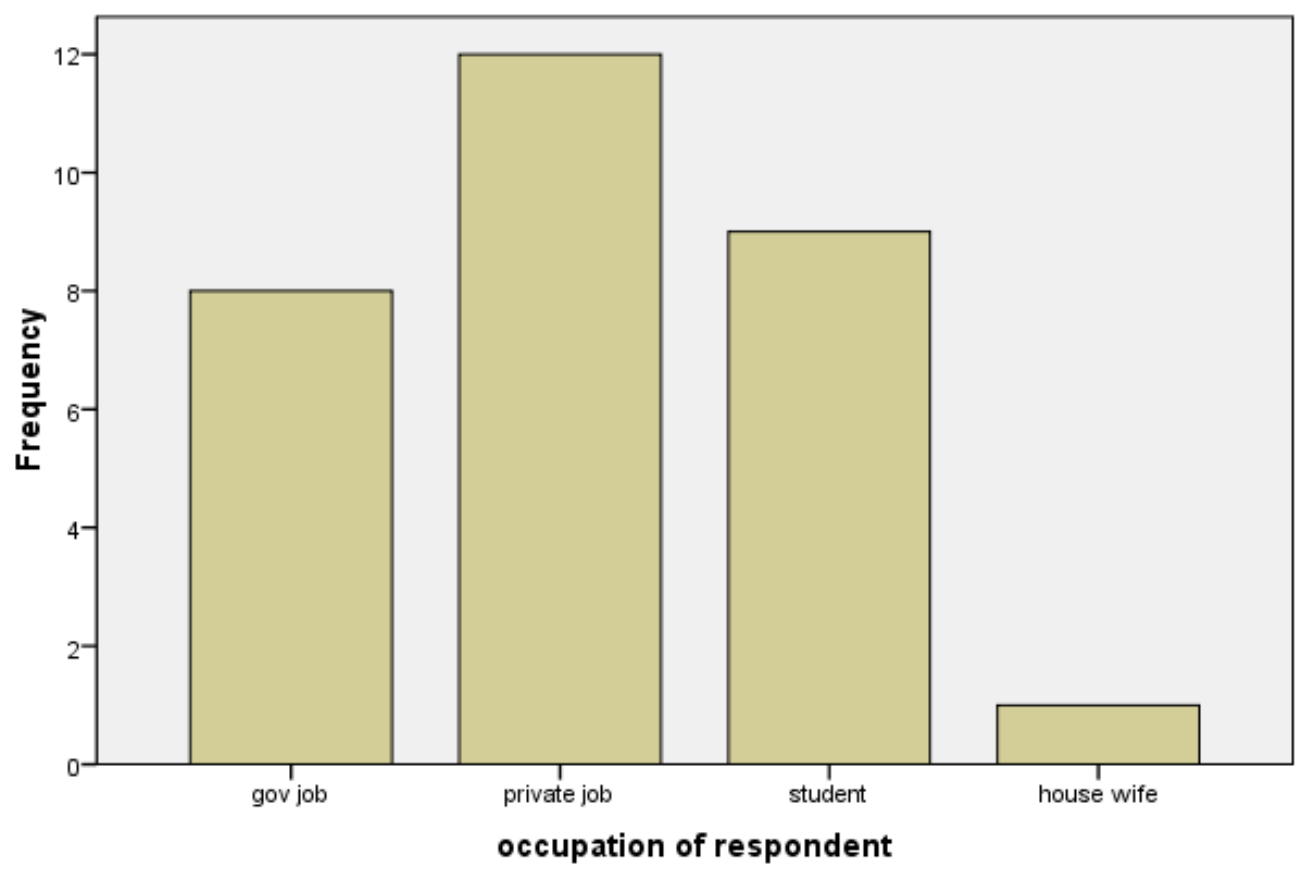

Figure 3: Occupation

The above table and figure show the distribution of occupation of respondents. According to results the respondents which have government job are $8(26.7 \%)$, private job respondents are $12(40 \%)$, students are $9(30 \%)$ and housewife is $1(3.3 \%)$.

Table 4: Qualification

\begin{tabular}{|l|c|c|}
\hline & Frequency & Percent \\
\hline Metric & 1 & 3.3 \\
\hline Fsc,b.com & 3 & 10.0 \\
\hline
\end{tabular}




\begin{tabular}{|l|c|c|}
\hline Ba/BSc & 12 & 40.0 \\
\hline MSc/MBA & 14 & 46.7 \\
\hline Total & 30 & 100.0 \\
\hline
\end{tabular}

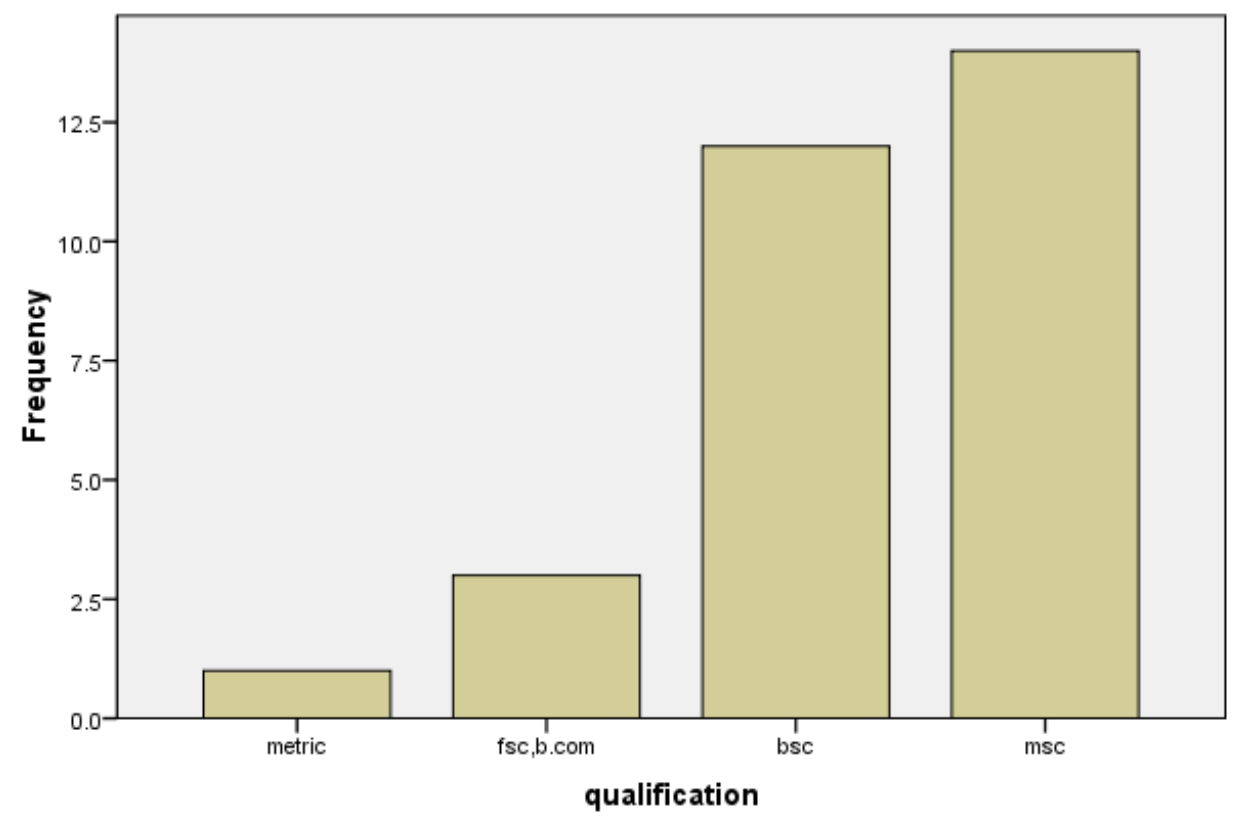

Figure 4: Qualification

The above table and figure show the qualification distribution of respondents .the results shows that the qualification of respondents up to metric is $1(3.3 \%), \mathrm{FSc}$ is $3(10 \%)$, BSc are $12(40 \%)$ and respondents which have master level qualification are 14(46\%).

\section{CONCLUSION}

The study was conducted on the service quality, customer satisfaction, and loyalty in the banking sector. After the completion of the study, the following conclusion based on descriptive statistics can be deducted. From the result of the present day, we found that the majority of the respondents were male, out of 30 respondents 21 (70\%) are male and 9(30\%) respondents are female. Most of the respondents have an age between 20 to 30 years which are 20(67\%) out of 30 samples. the occupation of the respondents was different in which most of the respondents belong to the private job which is $12(40 \%)$ out of total samples. The qualifications of most of the respondents have Master or MBA level education which are 12 (46\%) out of total respondents. We also find out that different respondents have accounts in different banks of Peshawar sadder and most of the respondents belong to the conventional type of bank which is $21(70 \%)$ out of total samples. Most of the respondents have current account $24(80 \%)$. The respondents also suggest that the bank does not charge unnecessarily charges. We also concluded 
that the ATM facility is more available on banks than other facilities in banks and the respondents said that the particular bank caters all our banking needs.

One of the basic objective of our study was to find out the satisfaction level of a customer on banking networking. We concluded that $25(80 \%)$ of respondents out of 30 were satisfied from the banking networking. We also concluded that the foremost problem to the customer from the banking side was ATM related problems. Most of the respondents said that the wide branch networking of banks comes first in our minds related to their bank, in which they have an account. We concluded that the banking services of particular banks were very good which is 15 $(50 \%)$ of the total sample. Most of the respondents 16(53\%) out of 30, visit bank 1 to 5 times in a month. We also concluded that most of the respondents trust completely on online banking security services. Human contact is also very important for banking relations.

We concluded that the main problem related to not visit the particular bank branch was waiting in banks branch and also distance from the branch from home is the main problem of not giving to banks. We also concluded that the personal information in banks was preserved in a particular bank. In the last, we concluded that most of respondents $26(76.6 \%)$ out of 30 are satisfy from the bank policies for the betterment of customer services.

\section{Recommendation for Future Research}

This research can be simulated in the same manner with a large sample size and more variety of variables influencing the loyalty of a customer towards its bank. As this research concludes that loyalty programs are important but not that much appreciated in the banking sector of Pakistan hence future researches can be conducted on how banks can give better loyalty and good services programs to the customers.

\section{REFERENCES}

Anderson, E. W., \& Sullivan, M. W. (1993). The antecedents and consequences of customer satisfaction for firms. Mark. Anderson, E. W., \& Sullivan, M. W. (1993).

Anderson, H., \& Jacobsen P. N. (2000). The antecedents and consequences of customer satisfaction for firms. Mark. Sci. Creating Loyalty: Its Strategic Importance in Your Customer Strategy. In S. A. Brown (ed.), Customer Relationship Management.

Angur, M. G., Nataraajan, R. \& Jahera, J. S. (1999). Service Quality in the banking industry: an assessment in a developing economy. International Journal of Bank Marketing.

Anthanassopoulos, A., Gounaris, S., \& Sathakopoulos, V. (2001).

Anton, J. (1996).Customer Relationship Management: Making Hard Decisions with Soft Numbers. Upper Saddle River: Prentice-Hall.

Bearden, W. O. \& Teel, J .E. (1983). Selected Determinants of Consumer Satisfaction and Complaint Reports.

Behavioral responses to customer satisfaction: an empirical study. European. J. Mark.

Bitner, M. J., Booms, B .H. \& Tetreault, M .S. (1990). Relationship marketing of servicesgrowing interest, Emerging Perspectives. Journal of the Academy of Marketing Science. 
The service Encounter: Diagnosing Favorable and Unfavorable Indents. Journal of Marketing.

Bleomer, J., \& Ruyter, K. D. (1998). On the relationship between store image, store satisfaction and store loyalty. Eur. J. Mark.

Bloemer, J., de-Ruyter, K. \& Wetzels, M. (1999). Linking perceived service quality and service loyalty: A multidimensional perspective. European Journal of Marketing.

Bontis, Nick, Booker, Lorne, D., \& Serenko, A. (2007).The mediating effect of organizational reputation on customer loyalty and service recommendation in the banking industry. Manage. Decision.

Johnson, M. D. \& Fornell, C. (1991). A Framework for comparing customer satisfaction across individuals and product categories. Journal of Economic Psychology, 12 (2): 267-286.

Jumaev, M., Prof. Dr. Kumar, D. M. and Hanaysha, J. R. M. (2012). Impact of relationship marketing on customer loyalty in the banking sector. Far East Journal of Psychology and Business, 6(3): 36-55.

Juran, J.M. (1988). Juran's quality control handbook. McGraw-Hill, New York, NY. Khalid, S., Mahmood, B., Abbas, M. \& Hussain, S. (2011). Customer satisfaction with service quality in conventional banking in Pakistan. International Journal of Marketing Studies, 3(4): 165-174.

Kheng, L.L., Mahamad, O., Ramayah, T., M. \& Rahim, Mosahab, R. (2010). The impact of service quality on customer loyalty: a study of banks in Penang. Malaysia. International Journal of Marketing Studies, 2(2): 57-66

Kotler, P., \& Keller, K. L. (2006). Marketing Management (pp. 402). New Delhi, India: PrenticeHall. Lewis, M. (2004). The influence of loyalty programs and short-term promotions on customer retention. Journal of Marketing Research, 41(3): 281-292.

Mesay Sata Shanka Bank Service Quality, Customer Satisfaction and Loyalty in Ethiopian Banking Sector. (2012) 